\title{
PENERAPAN PENDIDIKAN FINANCIAL PADA ANAK USIA SEKOLAH
}

\author{
Abdillah Mundir \\ Universitas Yudharta Pasuruan \\ Email: abdillahmundir@yudharta.ac.id
}

\begin{abstract}
A child's intelligence cannot only be measured by academic intelligence at school. Children's intelligence in regulating emotions, intelligence interacting in the social environment and also intelligence in managing finances are also part of a child's intelligence. To hone the financial intelligence of a child, it should begin to grow early, namely from the age of school to become a living culture in their daily lives. The success of the Indonesian economy is our success in preparing our children to prepare their future economies.
\end{abstract}

Kecerdasan seorang anak tidak bisa hanya diukur dari kecerdasan akademis di sekolah saja. Kecerdasan anak dalam mengatur emosi, kecerdasan berinteraksi di lingkungan sosial dan juga kecerdasan dalam mengatur keuangan juga menjadi bagian dari kecerdasan seorang anak. Untuk mengasah kecerdasan finansial seorang anak sebaiknya mulai ditumbuhkan sejak dini, yaitu sejak di usia sekolah agar menjadi budaya hidup di keseharian mereka. Suksesnya ekonomi bangsa Indonesia adalah kesuksesan kita dalam mempersiapkan anak-anak kita untuk menyiapkan ekonomi masa depan mereka.

Keywords: financial intelligence, school-age children

\section{A. PENDAHULUAN}

Pada era globalisasi seperti sekarang ini perlu kiranya menyiapkan anak-anak kita untuk lebih dini dikenalkan tentang kecerdasan finansial sebagai bekal untuk mereka memasuki persaingan ekonomi dimasa mendatang. Anak-anak perlu kita kenalkan dari dini untuk pengelolaan keuangan sederhana pada aktivitas keseharian mereka. Ini adalah fondasi kemampuan ekonomi bangsa di masa depan, tanggung jawab kitalah menyiapkan mereka untuk mampu mengelola keuangan sederhana pada keseharian mereka sebagai bekal di kehidupan mereka kelak. Pembentukan karakter di era global merupakan persoalan fundamental. Salah satu implementasi pembentukan karakter adalah melalui pengenalan tentang kecerdasan finansial kepada anak usia sekolah. Masa sekolah anak-anak kita isi dengan pemahaman dan karakter yang kuat sebagai bekal mereka kelak. Pendidikan anak usia sekolah tidak hanya terkait dengan upaya membekali mereka dengan tumbuh kembang yang memadai, tetapi juga penguatan karakter sejak awal. Kecerdasan finansial merupakan upaya mengajari anak untuk mampu memahami kegiatan atau aktivitas mengelola keuangan sehari-hari yang sederhana.

Lebih dari itu pendidikan finansial berarti juga mendidik anak bagaimana menggunakan uang dengan baik dan bijak. Ini termasuk pembentukan karakter dan pengenalan perilaku sosial yang baik. Kemampuan mengelola keuangan tidak mungkin hanya dicapai melalui pendidikan finansial dan akses finansial saja tetapi juga memerlukan adanya perubahan perilaku finansial setiap individunya, artinya pendidikan 
A L - MUDARRIS

Journal of Education

p ISSN: $2620-5831$ | e ISSN:2620-4355

finansial tidak serta merta mengubah perilaku finansial seseorang. Karena itu pendidikan finansial harus dilakukan terintegrasi dengan pendidikan perilaku sosial. ${ }^{1}$

Kecerdasan seorang anak tidak bisa diukur dari kecerdasan akademis di sekolah saja. Kecerdasan anak dalam mengatur emosi, kecerdasan berinteraksi di lingkungan sosial dan juga kecerdasan dalam mengatur keuangan juga menjadi bagian dari kecerdasan seorang anak. Untuk mengasah kecerdasan finansial, mengelola keuangan sebaiknya mulai ditumbuhkan sejak dini, yaitu sejak di usia sekolah agar menjadi budaya hidup di keseharian mereka.

Apabila ingin menumbuhkan kecerdasan finansial pada anak, berarti hal ini merujuk pada sebuah proses. Menumbuhkan itu dilakukan ketika masih kecil. Jadi tidak menunggu anak sudah besar baru kemudian dikenalkan tentang kecerdasan finansial yang tentunya akan lebih sulit nantinya.

Banyak yang memahami bahwa kecerdasan finansial identik dengan menabung, berhemat dan tidak boros. Padahal sebenarnya tidak sebatas itu saja. Karena kalau hanya aktivitas menabung saja, anak-anak sudah dapat melakukannya. Kecerdasan finansial merupakan proses pembelajaran pengendalian diri, sehingga akan berpengaruh pada perilaku mandiri dan pola pikir bijaksana pada usia dewasa. Ada beberapa cara untuk menumbuhkan kecerdasan finansial pada anak, yaitu :

1. Memahamkan anak tentang berbagai kebutuhan sehari-hari sesuai fase perkembangannya.

Kebutuhan masing-masing keluarga tentu berbeda-beda. Sebelum memberikan pemahaman, orang tua perlu memahami terlebih dahulu fase perkembangan anak. Sehingga dapat memberikan penjelasan yang tepat sesuai usia anak.

2. Memahamkan anak mengenai perbedaan keinginan dan kebutuhan.

Kebutuhan adalah sesuatu yang harus dipenuhi, ada atau tidak ada uang, misalnya, kebutuhan makan. Sedangkan keinginan adalah sesuatu yang pemenuhannya bisa ditunda dan tidak harus sekarang. Oleh karena itu, jika anak menangis meminta dibelikan sesuatu, jelaskanlah terlebih dahulu apakah itu kebutuhan atau hanya keinginan. Penjelasan ini bisa dilakukan dengan memberikan pengertian yang baik kepada anak. Utamanya adalah memberikan contoh dengan memulai dari diri orang tua dan guru sendiri sebagai teladan. Mengendalikan diri untuk tidak membeli barang dikarenakan alasan ada diskon, dan mampu berkomitmen hanya membeli barang yang dibutuhkan ketika belanja bersama anak.

4. Memberi kepercayaan anak untuk mengelola uang saku.

Sebaiknya penggunaan istilah uang jajan pada anak diganti dengan uang saku. Karena ini berpengaruh pada persepsi yang dimiliki anak. Uang saku adalah uang yang dapat dikelola penggunaannya, sedangkan uang jajan digunakan untuk membeli jajan dan bersenang-senang. Latihan pengelolaan keuangan, bisa dimulai dengan memberikan uang saku pada anak satu minggu sekali. Nah, untuk menerapkan hal ini orang tua harus dapat bersikap tega dan konsisten. Karena di awal prosesnya, terkadang uang saku satu minggu bisa dihabiskan anak hanya beberapa hari saja. Jika seperti itu, biarkan anak belajar merasakan konsekuensinya.

5. Mendampingi anak secara bertahap, ajarkan, buat kesepakatan, contohkan dan konsisten.

Pemberian uang saku diikuti dengan penjelasan bagaimana alokasinya. Sehingga anak memiliki gambaran bagaimana menggunakan uang sakunya. Bisa untuk membeli

\footnotetext{
${ }^{1}$ Yohanes Enggar Harisusilo, 2018, Kecerdasan Finansial Anak Usia Dini, https://edukasi.kompas.com

Vol. 1 No. 2 Oktober 2018

AL - MUDARRIS homepage: http://e-journal.staima-alhikam.ac.id/index.php/almudarris/index
} 
jajan, membeli perlengkapan sekolah yang rusak, dan menabung. Dengan diberi kepercayaan untuk mengelola uang saku, anak akan berpikir ulang dalam menggunakan uangnya. Dan jika menginginkan sesuatu anak akan berpikir bagaimana mendapatkan uang, misalnya berjualan. Sehingga tidak mudah minta uang pada orang tua. Hal ini perlu contoh dari orang tua dalam menerapkannya.

6. Memberi kesempatan anak untuk salah.

Apabila jatah uang saku anak seminggu namun dihabiskan dalam tiga hari, maka jangan serta merta memarahi anak. Berikan senyuman, ajak bicara dan cari tahu bagaimana penggunaan uangnya. Biarkan anak menceritakan dengan leluasa tanpa adanya tekanan. Kesalahan yang diperbuat anak bisa jadi memberikan pelajaran yang berharga.

7. Evaluasi dan lanjutkan proses belajar.

Setelah anak melakukan kesalahan, ajak anak berkomunikasi dengan baik. Kesediaan anak bercerita dengan jujur pada orang tua jauh lebih penting daripada berfokus pada kesalahannya. Dengan begitu, evaluasi bersama akan dapat dilakukan. Biarkan anak menemukan solusi dan apa yang seharusnya dilakukan agar kesalahan tidak terulang kembali.

8. Anak berhak dan wajib berkontribusi dalam pembiayaan acara keluarga.

Misalnya untuk acara liburan bersama yang sudah direncanakan jauh hari. Diskusikan bersama akan pergi ke mana, dana yang dibutuhkan. Ajak anak untuk berkontribusi sesuai kemampuannya untuk mewujudkan liburan bersama tersebut, misalnya acara ulang tahun anggota keluarga.

9. Apresiasi keberhasilan anak walaupun kecil.

Dengan memberikan apresiasi anak akan termotivasi memperbaiki untuk menghasilkan keberhasilan yang lebih besar.

10. Ganti kritik dengan evaluasi bersama.

Evaluasi bersama akan menstimulasi anak untuk menemukan solusi dan kesepakatan untuk menjadi lebih baik lagi. $^{2}$

Stimulasi kecerdasan finansial bisa dimulai sejak dini. Terutama jika anak sudah minta dibelikan sesuatu, artinya anak sudah mengerti tentang uang. Sehingga mulai dapat distimulasi kecerdasan finansialnya. Saat anak beranjak di bangku sekolah, yang terpenting adalah menanamkan jiwa wirausaha. Apabila anak menginginkan sesuatu tidak harus beli tapi bisa dicoba untuk membuatnya sendiri bersama orang tua.

Kunci utama dari keberhasilan pengasuhan anak adalah adanya teladan. Begitu juga saat ingin menumbuhkan kecerdasan finansial pada anak. Orang tua harus belajar dan dapat mengendalikan diri. Memilah mana yang menjadi kebutuhan dan keinginan. Melalui contoh akan lebih mudah bagi anak untuk memahami dan menerapkannya. Selain itu, berikanlah kesempatan dan kepercayaan pada anak untuk mengelola keuangannya sendiri. Jika anak melakukan kesalahan, tanggapi dengan senyum dan bantu anak untuk belajar dari kesalahannya.

Sebagai orang tua pastinya kita menginginkan anaknya menjadi orang yang sukses, untuk itu mereka membekali anak-anaknya dengan kecerdasan akademis yang tinggi. Namun, memiliki kecerdasan akademis saja tentu belum cukup untuk mewujudkan standar kesuksesan dalam kehidupan yang diinginkan. Oleh karena itu, anak-anak perlu dibekali dengan kecerdasan non akademis yang mendukung pada

\footnotetext{
${ }^{2}$ Abyz Wigati, 2017, Menumbuhkan Kecerdasan Finansial Pada Anak, mayamyworld.wordpress.com

Vol. 1 No. 2 Oktober 2018

AL - MUDARRIS homepage: http://e-journal.staima-alhikam.ac.id/index.php/almudarris/index
} 
kehidupannya kelak. Salah satu bentuk pendidikan non akademis yang bisa diberikan adalah pendidikan finansial.

\section{B. DEFINISI KECERDASAN FINANSIAL PADA ANAK}

Pendidikan finansial adalah tindakan mengajari anak untuk bisa memahami ilmu keuangan. Dengan menerapkan pendidikan finansial, anak-anak diajari cara mengelola uang dengan baik. Tujuan dari pendidikan finansial ini agar anak terbiasa mengatur masalah finansialnya sejak dini. Jika pendidikan finansial ini sudah diajarkan sejak kecil, maka anak bisa memahami mana kebutuhan yang harus diutamakan, dan mereka bisa belajar untuk menyimpan uang serta mana keinginan yang harus dikesampingkan untuk menghemat pengeluaran sendiri. Kecerdasan finansial terdiri atas dalam 3 hal, antara lain:

1. Kemampuan menyimpan banyak uang yang diikuti kemampuan membuat uang bekerja.

2. Kemampuan mengubah uang kontan atau kerja menjadi aset yang memberikan penghasilan.

3. Kemampuan mengakali uang. ${ }^{3}$

Untuk mencapai kesuksesan, tidak hanya diperlukan kecerdasan secara akademis saja tetapi juga kecerdasan mental dan emosional. Seseorang yang mempunyai IQ (intelegence qoutient) tinggi tapi EQ (emotional qoutient) rendah cenderung mengalami kegagalan yang lebih besar dibanding dengan orang yang IQ-nya rata-rata tetapi EQ-nya tinggi. Artinya bahwa penggunaan EQ atau olah rasa justru menjadi hal yang sangat penting dalam dunia kerja, yang berperan dalam penunjang kesuksesan seseorang dalam pekerjaan dan bisnis. Dalam dunia kerja, yang berperan dalam kesuksesan karir seseorang adalah $85 \%$ EQ dan $15 \%$ IQ. ${ }^{4}$

Kecerdasan finansial pada anak adalah kemampuan seseorang seorang anak untuk mengelola sumber daya yang dia miliki untuk memaksimalkan potensi dalam mengelola keuangannya. Kecerdasan finansial meliputi 4 hal antara lain yaitu: bagaimana mendapatkan uang, bagaimana mengelola uang, bagaimana menyimpan uang, dan bagaimana menggunakan uang.

Orang-orang sukses biasanya memiliki kecerdasan finansial yang bagus. Mereka mampu mengelola uang sehingga aset terus bertambah, dan bahkan ada yang sampai pada tahap merdeka secara finansial. ${ }^{5}$ Kecerdasan finansial secara best practice paling tidak meliputi berbagai aspek, antara lain:

1. Bagaimana menghasilkan uang dengan cara yang produktif,

Seorang anak mendapatkan uang dari uang saku yang diterimanya dari orang tua. Namun masalahnya, apakah cara memperoleh uang tersebut sudah produktif? Sebaiknya perlu diajarkan pula cara cara lain dalam menghasilkan uang, misalkan dengan cara berjualan mainan atau dengan cara mendapatkan upah dari pekerjaan rumah yang dia lakukan, ini akan memotivasi kreatifitas anak dalam penghasilkan uang selain dari uang saku.

2. Bagaimana melindungi uang yang sudah diperoleh.

\footnotetext{
${ }^{3}$ Robert T. Kiyosaki, 2000, Rich Dad, Poor Dad, Gramedia Pustaka Utama

${ }^{4}$ Daniel Goleman, 2006, Emotional Intelligence Why it Can Matter More Than IQ, Bantam Books, New York

${ }^{5}$ Elvyn G Masassya, 2012, 4 Langkah Mencapai Kecerdasan Finansial, https://lifestyle.kompas.com/read/2012/10/29/10040396/4.langkah.mencapai.kecerdasan.finansial/ Vol. 1 No. 2 Oktober 2018

AL - MUDARRIS homepage: http://e-journal.staima-alhikam.ac.id/index.php/almudarris/index
} 
Ada kalanya uang yang diperoleh seorang anak dengan mudah, akan mudah pula habisnya. Perlu diajarkan pula untuk melindungi keuangan dengan cara menabung. Perlu pula kita ajarkan kepada anak untuk menabung di bank atau berinvestasi untuk mengkonfersi uang yang didapatkannya.

3. Mengelola keuangan secara efektif.

Pembiayaan konsumtif yang dilakukan oleh seorang anak harus berdasarkan perencanaan yang sudah dia buat sendiri, yaitu setiap uang yang dibelanjakan mestinya berdasarkan suatu kebutuhan, dan sudah dianggarkan sebelumnya. Semua pembelanjaan harus terencana, lalu dieksekusi dan kemudian bisa dievaluasi di mana penyimpangannya. Berapa besar penyimpangan tersebut dan selanjutnya dievaluasi bersama untuk memperbaiki perilaku keuangan yang dianggal perlu dikoreksi. Perlu dikenalkan pula sejak dini tentang kemerdekaan finansial, yaitu kondisi pengeluaran uang lebih sedikit dari pada pemasukan uang yang diterima seorang anak.

\section{LIMA KECERDASAN FINANSIAL ANAK YANG WAJIB DIKUASAI}

Kecerdasan finansial tidak berbanding lurus dengan kecerdasan akademik. Artinya, memiliki kecerdasan akademik yang bagus tidak serta merta membuat anak lebih cerdas dalam urusan keuangan. Urusan uang tidak mengenal gelar dan umur. Tidak heran, banyak orang yang tiba-tiba menjadi bodoh saat berhadapan dengan urusan keuangan. Kita perlu meluangkan waktu untuk mempelajari keterampilan finansial secara khusus jika kita ingin anak kita mahir dalam menghasilkan dan mengelola uang. Ada lima kecerdasan tentang uang yang wajib dimiliki seseorang jika kita ingin sejahtera secara finansial. ${ }^{6}$

1. Kecerdasan dalam menghasilkan uang.

Kecerdasan ini diukur dari kemampuan Anda menghasilkan uang. Elemen pertama dalam membangun kekayaan bukanlah uang itu sendiri, namun kemampuan Anda dalam menciptakan nilai bagi orang lain dan mengubahnya menjadi uang. Untuk meningkatkan kemampuan kita dalam menghasilkan uang kita perlu belajar meningkatkan kemampuan bisnis kita dalam membaca peluang usaha dan membaca potensi yang ada disekitar kita.

2. Kecerdasan dalam melindungi uang.

Banyak orang yang sangat baik dalam menghasilkan uang namun sangat buruk dalam melindungi uang yang mereka hasilkan. Sebaiknya kita menghindari penawaran belanja konsumtif, penawaran kredit, penawaran investasi yang tidak jelas, atau penawaran peluang bisnis yang menggiurkan namun kita tidak memahami bidangnya. Fatal akibatnya apabila kita menyalurkan uang kita ke saluran-saluran yang tidak jelas, tidak terukur, dan tidak tahu kapan kembalinya. Kebocoran finansial adalah masalah serius yang butuh penanganan serius apabila kita tidak ingin kerja keras kita menjadi sia-sia belaka.

3. Kecerdasan dalam mengalokasikan uang.

Orang yang cerdas dalam mengalokasikan uang memilki panduan yang jelas berapa persen dari penghasilannya yang akan ia gunakan untuk konsumsi, berapa persen yang ia akan gunakan untuk investasi, berapa persen yang akan ia gunakan untuk kegiatan sosial. Mereka punya patokan anggaran yang jelas sehingga pengelolaan keuangan mereka pun lebih terarah. Sekecil apapun penghasilan kita, mulailah membuat alokasi yang jelas kemana uang kita perlu diarahkan.

\footnotetext{
${ }^{6}$ Darmawan Aji, 2015, 5 Kecerdasan Tentang Uang yang Wajib Anda Kuasai. https://www.darmawanaji.com/5-kecerdasan-tentang-uang-yang-wajib-anda-kuasai/ Vol. 1 No. 2 Oktober 2018

AL - MUDARRIS homepage: http://e-journal.staima-alhikam.ac.id/index.php/almudarris/index
} 
4. Kecerdasan dalam mengungkit uang.

Mengungkit artinya bagaimana menggunakan tenaga kecil untuk menghasilkan tenaga yang lebih besar. Mengungkit uang memiliki arti yang sama. Bagaimana menggunakan uang kecil untuk menghasilkan uang yang lebih besar. Tiga orang yang memiliki uang yang sama, katakanlah satu juta, bisa jadi memiliki akhir yang berbeda bergantung bagaimana mereka mengolah uang yang mereka pegang. Ada yang mungkin berakhir dalam kondisi berhutang. Ada yang berhasil menghasilkan dua juta rupiah. Ada juga yang mungkin berhasil menghasilkan sepuluh juta rupiah dari uang satu juta yang mereka miliki.

5. Kecerdasan dalam mencari informasi keuangan.

Faktor utama untuk melatih keempat kecerdasan di atas adalah kecerdasan kelima ini: kemampuan kita untuk mencari informasi keuangan dari sumber yang valid. Tanpa kemampuan ini kita akan tersesat di dalam hutan informasi keuangan yang beredar di atas bumi ini. Tanpa informasi yang berkualitas, kita tidak akan mampu membaca peluang dengan tepat. Tanpa informasi yang tepat, kita akan terjebak dalam investasi yang tidak jelas. Tanpa informasi keuangan yang benar, kita tidak akan berhasil menghasilkan dan mengembangkan uang kita sesuai yang kita harapkan. Jangan kita pernah berinvestasi pada bidang yang tidak kita fahami.

Dalam perspektif kecerdasan finalsial anak, lima hal diatas dapat diartikan sebagai berikut:

1. Perlunya mengenalkan anak dalam menghasilkan uang selain uang saku.

2. Perlu kita kenalkan kepada anak budaya hidup hemat dan menjauhkan dari perilaku hidup boros.

3. Perlu kita bimbing anak untuk dapat membuat perencanaan keuangan kereka dan berusaha untuk disiplin dalam belanja sesuai rencana keuangan yang sudah dibuat.

4. Sedari dini perlu kita kenalkan kepada anak bagaimana menginvestasikan uang dalam bentuk tabungan dan aset lain.

5. Perlu kita kenalkan pula apa itu uang dan transaksi jual beli serta bagaimana memperoleh penghasilan dari berdagang, untuk mengasah keberanian anak untuk menjual sesuatu.

Perlunya sedari dini perlu diajarkan kepada anak apa itu uang serta sifat dari uang serta purlu pula diajarkan bagaimana cara mengelola keuangan secara sederhana. Guru dan orang tua harus berperan aktif dalam mengajarkan tentang kecerdasan finansial sebagai bekal seorang anak daam menjalani kehidupan kelak. Cerdas finansial, maka sukses pula masa depan seorang anak. Kecerdasan finansial bukan berfokus pada uang tetapi lebih berfokus pada perilaku manusianya. ${ }^{7}$ Seorang anak harus diajarkan untuk mempunya tujuan hidup yang lebih jelas dan spesifik. Anak perlu diajarkan menuliskan dengan jelas apasaja yang menjadi keinginannya dimasa depan. Hal ini akan membuat perilaku finansial seorang anak akan lebih terarah dan terfokus pada tujuan tersebut. Anak akan lebih mudah diajak untuk menabung apabila mempunyai tujuan yang lebih jelas tentang apa yang sangat diinginkannya. Orang tua mempunyai pengaruh besar terhadap kecerdasan finansial anak. ${ }^{8}$ Anak yang cerdas finansial adalah

\footnotetext{
${ }^{7}$ William Tanuwidjaja, 2009, 8 Intisari Kecerdasan Finansial, MedPress, hal 23

${ }^{8}$ Muslima, 2015, Pola Asuh Orang Tua Terhadap Kecerdasan Finansial Anak, Gender Equality Journal ISSN-P 2461-1468, E-ISSN-E 2548-1959 Vol 1 No 1 (2015) hal 85

Vol. 1 No. 2 Oktober 2018

AL - MUDARRIS homepage: http://e-journal.staima-alhikam.ac.id/index.php/almudarris/index
} 
A L - MUDARRIS

Journal of Education

p ISSN: $2620-5831$ | e ISSN:2620-4355

seorang anak yang mampu mendapatkan dan mengelola keuangan sesuai dengan tujuan dan keinginan yang telah direncanakannya. ${ }^{9}$

\section{CARA PENERAPAN PENDIDIKAN FINANSIAL PADA ANAK}

Anak-anak perlu dipahamkan terlebih dahulu bahwa rezeki itu datang dari Sang Maha Pemberi Rezeki, sangat luas dan banyak, uang atau gaji orangtua itu hanya sebagian kecil dari rezeki. Sehingga jangan batasi mimpi anak, dengan kadar rejeki orangtuanya saat ini. Karena sejatinya Anak-anak adalah milik Dia Yang Maha Kaya, bukan milik kita. Sehingga kalau akan minta sesuatu yang diperlukan anak, mimpi sesuatu, mintalah ke Dia Yang Maha Kaya, bukan ke manusia, meski itu orangtuanya.

Perlu menjelaskan kepada anak tentang kebutuhan dan kenginan. Kebutuhan adalah sesuatu yang tidak bisa ditunda. Keinginan adalah sesuatu yang bisa ditunda. Bantu anak-anak membuat skala prioritas kebutuhan hidupnya berdasarkan dua hal tersebut di atas. Setelah anak paham dengan prioritas kebutuhan hidupnya, maka latih anak untuk membuat mini budget, sebagai bentuk latihan merencanakan berdasarkan skala prioriitas. Mini budget ini bisa dibuat 3 harian, 1 minggu atau 1 bulan bergantung pada kemampuan dan usia anak. Dengan adanya mini budget ini anak akan berkomitmen untuk mematuhi apa yang sudah disepakati, kemudian bertanggung jawab menerima konsekuensi apapun atas kesepakatan yang sudah dibuatnya.

Berikut ini adalah 7 cara yang dapat dilakukan agar anak bisa memprektekkan cerdas finansial:

1. Mengajarkan dengan contoh

Dalam hal ini, sebagai orang tua di mana tingkah laku dan kebiasaan yang sehari-harinya kita lakukan dapat dilihat dan ditiru oleh anak hendaknya juga harus dapat mencontohkan nilai-nilai yang kita harapkan ada pada si anak. Jika menginginkan anak gemar menabung, contohkanlah dengan menabung juga. Cara yang paling sederhana adalah ajak anak untuk menabung ke bank saat kita menabung, berikan pula penjelasan pentingnya menabung untuk mendukung perencanaan finansial dimasa yang akan datang. Dengan sendirinya, anak pasti juga akan mulai mengikuti kebiasaan kita.

2. Beri penjelasan

Contoh akan menjadikan anak dapat melakukan hal serupa, namun belum tentu langsung mengerti apa maksud meberikan contoh tersebut. Jadi perlu penjelasan kepada anak mengapa mereka harus gemar menyisihkan dana yang didapat. Jangan lupa untuk sebutkan keuntungannya terutama untuk masa depan mereka. Tidak lupa, berikan juga prinsip-prinsip klasik semisal rajin pangkal pandai dan hemat pangkal kaya. Anak akan terus mengingat hal-hal yang sering kita ucapkan dan diharapkan dapat melakukannya dalam tindakan nyata.

3. Jangan memaksa

Sebagai orang tua, tentu akan dituntut hadirnya sifat sabar dan disiplin dalam mengajarkan hal-hal baik kepada anak. Dalam hal ini, biarkan anak menabung dan melakukannya dengan sukarela tanpa paksaan dari orangtua. Semakin tertarik anak untuk menabung, berikanlah penghargaan yang juga semakin besar sehingga anak merasa memiliki banyak keuntungan dengan melakukan hal tersebut.

4. Lakukan sejak dini

Sering kita mendengar bahwa sifat orang tua sudah sulit untuk diubah. Oleh karena itu, mumpung anak masih dalam pengawasan dan kontrol orang tua,

\footnotetext{
${ }^{9}$ Institut Ibu Profesional, 2017, Mendidik Anak Cerdas Finansial Sejak Dini, https://ummuchelia.wordpress.com

Vol. 1 No. 2 Oktober 2018

AL - MUDARRIS homepage: http://e-journal.staima-alhikam.ac.id/index.php/almudarris/index
} 
tanamkanlah sifat gemar menabung sejak dini. Semakin dini anak berlatih menabung, semakin besar pula manfaat yang bisa diambil terutama untuk masa depannya. Ingat, kebiasaanlah yang akan membentuk karakter dan perilaku seseorang di kemudian hari.

5. Orang tua dan guru dituntut lebih kreatif

Jangan hanya mengharapkan anak dapat tertarik untuk menabung, orang tua juga harus dapat mencari cara yang dapat menumbuhkan minat sang anak untuk melakukan hal-hal yang dianggap baik. Seorang anak senang dengan bermain, ini jelas karena mereka melakukannya dengan hati senang. Kita perlu mencari, apa daya tarik menabung dapat membangkitkan perasaan senang bagi anak. Berikan celengan dengan bentuk yang menarik, buatlah juga kejutan apabila anak berhasil mengisinya dengan penuh dengan memberikan celengan lain yang sesuai dengan tokoh atau animasi kegemarannya.

6. Mengenalkan kepada bank

Pada kondisi saat ini, di mana teknologi informasi sudah berkembang pesat, perbankan sudah berbondong-bondong menawarkan produk yang memang mereka ciptakan untuk kalangan anak-anak. Tentu tidak ada salahnya untuk mengenalkan produk bank pada anak. Jelaskan keuntungan yang didapat apabila menabung di bank tersebut, selain memanfaatkan adanya fasilitas lebih yang dapat diterima anak. Dengan mengajak ke ATM, anak-anak juga dapat sekaligus diajarkan bahwa ternyata ATM bukanlah mesin pencetak uang yang dapat diambil tanpa batas.

7. Biarkan anak membuat keputusan

Jika uang sudah terkumpul, sesekali biarkan anak memilih barang apa yang ia inginkan, yang bisa dipilih sesuai dengan kebutuhannya atau bisa juga mengajak anak ke tempat yang mereka inginkan. Apabila hal ini berhasil dilakukan, ke depannya anak akan terbiasa untuk berkorban terlebih dahulu sebelum mendapatkan hal yang diinginkan. Selain itu, mereka juga akan dilatih agar terbiasa untuk menghargai apa yang telah dimiliki karena didapatkan dari hasil usahanya untuk menyisihkan sebagian uang yang dimiliki.

\section{E. PENGEMBANGAN KECERDASAN FINANCIAL DI SEKOLAH DASAR}

Tidak ada alasan untuk tidak dapat mengajarkan kepada anak pentingnya mengatur keuangan semenjak kecil. Orang tua dan guru akan berperan besar dalam menyukseskan pembentukan karakter anak terutama terkait dengan keuangan. Jadi, Nikmati saja setiap proses yang ada dan yang terpenting semua ini dilakukan agar ke depannya anak sadar akan pentingnya memiliki perencanaan keuangan yang dapat membawa semua kepada tujuan yang ditetapkan.

Hasil riset menunjukkan bahwa hanya 13 persen orang tua yang percaya bahwa anak-anak mereka memiliki ketrampilan pengelolaan keuangan dengan baik. ${ }^{10}$ Bukan hanya orang tua yang bertanggung jawab mengajarkan kecerdasan finansial kepada anak-anak, guru dan satuan pendidikanpun punya tanggung jawab yang sama. Sekolah dan madrasah juga berkewajiban mengajarkah kal tersebut kepada peserta didiknya. Sekolah akan kehilangan relevansinya apabila tidak mengajarkan kecerdasan finansial kepada anak-anak didiknya melalui pendidikan kewirausahaan dan ilmu manajemen keuangan. Pemkot Sidoarjo melalui Dinas Pendidikan dan Kebudayaan Sidoarjo bekerjasama dengan lembaga Prestasi Junior Indonesia menjalankan program ChaChing Curriculum.

\footnotetext{
${ }^{10}$ Thomas A. Lucey, 2018, Financial Literacy for Children and Youth, Second Edition, Peter Lang AG International Academic Publishers.

Vol. 1 No. 2 Oktober 2018

AL - MUDARRIS homepage: http://e-journal.staima-alhikam.ac.id/index.php/almudarris/index
} 
Program Cha-Ching Curriculum (C-3) adalah program pendidikan yang mengajarkan pengelolaan keuangan bagi anak Sekolah Dasar. Program ini dijalankan pada 602 SD dengan melibatkan 29.850 siswa dan 966 guru. Program tersebut program literassi keuangan yang didesain untuk siswa SD, program ini ini menjalankan pembelajaran ekonomi dan sosial yang lebih memfokuskan pada ruang lingkup keuangan, siswa didorong untuk berfikir kritis dan kreatif dalam membuat keputusan dengan menerapkan konsep : mendapatkan (earn), menabung (save), membelanjakan (spend), menyumbang (donate) dalam kehidupan sehari-hari. ${ }^{11}$ Berbekal empat konsep tersebut diharapkan siswa dapat bijaksana dalam pengelolaan keuangan mereka sehingga harapannya kelak dikemudian di masa datang mereka akan dapat membedakan kebutuhan dan keinginan. Kelak anak-anak tersebut akan menjadi pribadi-pribadi yang mandiri dalam finansial yang mempunyai kecerdasan financial yang kuat.

\section{F. MEMOTIVASI ANAK UNTUK BERHEMAT}

Hemat adalah perkara yang cukup sulit dilakukan oleh anak-anak, bahkan orang tua sekalipun. Itulah mengapa, mendidik anak sejak dini untuk bisa berhemat adalah pekerjaan yang tidak gampang bagi seluruh orang tua. Orang tua harus bisa membuat anak bersikap hemat dan memotivasi mereka agar pandai mengelola uang saku. Dengan mendorong anak agar mau hemat, maka mereka akan terbiasa dengan sikap ini sejak dini dan akan menjadi gaya hidupnya hingga dewasa kelak.

Berikut ini lima cara yang dapat diterapkan untuk yang memotivasi anak untuk berhemat: $^{12}$

1. Biarkan Anak Bermimpi Ingin Memiliki Sesuatu

Kita memang tidak bisa secara langsung menyuruh anak menabung tanpa memberikan penguatan motivasi positif kepada mereka. Untuk tahap-tahap awal, tanyalah apa yang mereka inginkan sekarang. Jelaskan kepada anak bahwa benda itu bisa dibeli dengan cara menabung uang saku mereka. Yang paling penting adalah membuat anak mau mewujudkan keinginannya dengan usaha sendiri. Jika anak bermimpi tentang sesuatu yang kurang memberikan manfaat, orang tua mencoba mengalihkan ke hal yang lebih berguna. Misalnya liburan ke taman bermain yang memiliki zona edukasi, atau membeli sesuatu yang bisa menunjang belajar. Anak bisa bermimpi dengan bebas, namun tetap harus terarah.

2. Berikan Terapi Uang Terbatas Kepada Anak

Salah satu cara mudah agar anak bisa belajar hemat adalah degan memberikan uang saku yang terbatas. Katakan kepada mereka jika uang yang dipotong akan disimpan oleh ayah dan bunda. Kelak jika saatnya tiba, uang itu bisa diambil dan digunakan untuk keperluan lain yang bermanfaat untuk anak. Buat penjelasan sesederhana mungkin agar anak-anak paham dan tidak melakukan protes. Dengan uang yang terbatas, mereka akan pandai-pandai mengelola uang saku agar jangan sampai kehabisan uang saku. Jika kebiasaan ini ditanamkan sejak dini, anak-anak akan terbiasa dengan uang yang terbatas. Jika kelak diberi uang dengan nominal yang jauh lebih banyak. Anak-anak akan langsung terbiasa menyimpannya dan tidak menggunakannya secara sembarangan.

\footnotetext{
${ }^{11}$ Jawa Post, 2018, Mengembangkan Kecerdasan Finansial Siswa, https://www.pressreader.com/indonesia/jawa-pos/20180327/282651803033679

${ }^{12}$ Naila, 2018, 5 Cara Memotivasi Anak agar Selalu Hemat dengan Uang yang Dimiliki, https://nailatazkiyya.wordpress.com

Vol. 1 No. 2 Oktober 2018

AL - MUDARRIS homepage: http://e-journal.staima-alhikam.ac.id/index.php/almudarris/index
} 


\section{Ajak Anak Memiliki Target Keuangan}

Kita bisa memberikan target kepada anak dalam jangka waktu seminggu, sebulan, atau bahkan satu tahun. Jika mereka bisa mengumpulkan uang sejumlah yang telah disepakati. Mereka akan mendapatkan apa yang mereka inginkan. Misalnya jika mereka mampu mengumpulkan cukup banyak uang, anak akan diberikan komputer atau laptop agar bisa membantunya belajar di rumah. Dengan memberikan target seperti ini, anak-anak akan semakin rajin menabung. Mereka tidak akan sembarangan menggunakan uangnya. Jika sampai target tidak dicapai, maka apa yang mereka inginkan tidak akan terpenuhi. Memberikan dorongan seperti ini tidaklah salah. Tapi saat anak-anak mampu mencapai targetnya, orang tua tidak boleh ingkar. Jika sampai hal ini terjadi karena anak-anak akan malas untuk diajari hemat lagi.

4. Mengajarkan Dampak Perilaku Boros

Anak tidak akan mudah percaya jika tidak diberikan contoh yang konkret. Itulah saatnya orang tua mengajarkan perihal hemat, beri tahu juga kepada mereka tentang bahaya boros. Katakan sesuatu yang sederhana, misalnya jika boros, dia tidak akan bisa membeli makanan. Jika boros tidak akan ada uang untuk membiayai kebutuhan anak. Boros hanya akan membuat seseorang jadi susah.

5. Beri Contoh Nyata Tentang Berhemat

Cara terkahir yang bisa dilakukan agar anak semakin termotivasi untuk hemat adalah dengan langsung memberikan contoh. Saat kita akan menabung, ajak anak ikut serta agar melihat tata caranya. Perlihatkan benda-benda yang bisa dibeli dengan hemat dan menabung. Perlihatkan juga jika kendaraan atau rumah yang ditempati juga diperoleh dengan cara bersikap hemat. Jika kita ingin anak-anak bersikap hemat, jangan ajari mereka perilaku boros seperti membeli barang tak berguna, memanjakan dengan memberikan apapun permintaan anak. Pada dasarnya, anak-anak akan termotivasi jika melihat contoh secara langsung dan diberi penguatan positif. Meski hanya dengan mengucapkan kata pujian untuk anak: bagus, hebat! Anak akan menjadi lebih bersemangat untuk berhemat dan menabung.

\section{G. PENTINGNYA PENDIDIKAN FINANSIAL DISEKOLAH}

Kurikulum cerdas finansial yang berkualitas dapat membuat siswa lebih termotivasi untuk mempersiapkan sejak dini, serta menyiapkan siswa pada kehidupan masa depan yang terencana. Pengaplikasian ilmu cerdas finansial yang teradaptasi dengan kurikulum tempat siswa belajar memberikan kesempatan bagi siswa mengenal pembelajaran pengelolaan keuangan di kehidupan nyata, kususnya disekolah dalam pendampingan guru.

Perilaku finansial seseorang sangat di pengaruhi oleh pendidikan finansial yang di dapat ketika usia sekolah. Kecerdasan finansial harus diasah sejak dini di lingkungan sekolah, dengan begitu anak akan memiliki kecerdasan finansial sejak dini. Anak akan mampu membaca, memahami, dan mengendalikan keuangannya. Karena itu, beberapa aspek dasar harus di pahami. Salah satunya adalah konsep uang sebagai alat tukar.

Konsep yang dimaksud diatas dalam arti guru harus memberi pengertian bahwa jika anak menginginkan sesuatu, ia harus memiliki uang untuk dapat memiliki apa yang anak kita inginkan. Bila uang yang di miliki tidak cukup, maka guru dan orang tua juga harus mengajarkan, bagaimana cara anak untuk menahan keinginannya tersebut.

Sebagai guru dan orang tua jangan membiasakan anak mendapatkan sesuatu kemudian orangtua tinggal membayar. Apalagi jika anak kita sudah masuk sekolah, guru harus memperkenalkan uang tidak hanya untuk di belanjakan, tetapi disisihkan

Vol. 1 No. 2 Oktober 2018

AL - MUDARRIS homepage: http://e-journal.staima-alhikam.ac.id/index.php/almudarris/index 
untuk di tabung atau disumbangkan kepada yang membutuhkan sebagai donasi atau sedekah untuk memupuk jiwa sosial sang anak.

Pada masa sekolah inilah penting mengajari anak untuk melek finansial. Antara guru dan orang tua harus berbagi tugas, sebagai orangtua dapat mengatur uang saku, misalnya mulai SD harian, mulai SMP mingguan, dan SMA bulanan dan guru mengawasi anak disekolah bagaimana uang saku tersebut digunakan. Namun, hal terpenting yang harus ditanamkan pada anak adalah uang bukan semata-mata untuk jajan yang bisa dihabiskan dalam waktu sesaat tapi perlu disisihkan untuk kebutuhan lain dikemudian hari. Karena itu, orang tua tidak perlu memberi bagian terpisah antara uang jajan dan tabungan karena anak butuh diberikan kepercayaan untuk mengatur sendiri keuangannya. Sebaiknya sekolah juga bisa mengadakan program tabungan siswa yang dikoordinir guru dan sekolah. Tujuannya bisa untuk berjaga-jaga atau akan digunakan untuk membiayai sesuatu, misalkan untuk kebutuhan studi tour ke luarkota yang pastinya membutuhkan biaya tidak sedikit.

Menabung erat kaitannya dengan kedisiplinan untuk kesuksesan pencapaian tujuan di kemudian hari. Sebelum usia sekolah, celengan bisa jadi sarana latihan. Nah, setelah memasuki usia sekolah, biasakanlah anak untuk memiliki target tabungan dalam jangka waktu tertentu. Upayakan agar menabung menjadi kegiatan rutinnya. Prinsip utamanya adalah agar anak mengerti bahwa jumlah uang yang bisa disimpan jauh lebih penting dibandingkan dengan jumlah uang yang didapat.

Lalu, ketika memasuki masa remaja, Anda bisa lebih terbuka tentang keuangan keluarga pada anak. Dengan begitu, ia sadar bahwa di dunia nyata tidak ada satupun pekerjaan yang bisa menjamin kepastian finansial seumur hidup. Tanamkan bahwa kecerdasan dan keterampilan finansial adalah modal yang sangat penting untuk survive dalam ketidakpastian.

Membantu anak-anak muda untuk memahami masalah-masalah keuangan adalah sesuatu hal penting, karena generasi muda akan menghadapi produk dan jasa keuangan yang cenderung semakin kompleks. Mereka juga cenderung harus menanggung lebih banyak risiko keuangan di masa dewasa daripada orangtua mereka, terutama dalam tabungan, perencanaan pensiun dan menutupi kebutuhan perawatan kesehatan mereka kelak dikemudian hari.

Kunci utama dalam membuat anak termotivasi untuk mengatur keuangan adalah membuat uang menjadi hal penting dalam hidup. Langsung saja pada intinya, uang. Guru harus bisa memberikan contoh nyata dalam keseharian di sekolah dan jadilah contoh bagi mereka dalam menyikapi masalah keuangan dengan mengajarkah beberapa hal berikut: ${ }^{13}$

1. Ajarkan siswa perbedaan antara kebutuhan dan keinginan.

Jelaskan pada mereka bahwa beberapa benda harganya mahal sekali dan untuk membelinya kita harus menabung terlebih dahulu. Hal ini akan membuat mereka bisa menahan diri dari keinginan berbelanja dan jajan di sekolah sesuai kebutuhan saja.

2. Biarkan siswa membuat keputusan soal uang sedini mungkin.

Ajarkan pada siswa cara mengatur uang saku, namun jangan paksa mereka. Berikan pemahaman bahwa dengan menabung mereka bisa mendapatkan barang berharga di kemudian hari

3. Berikan motivasi siswa untuk menabung.

${ }^{13}$ Andri Priyatna, 2012, Ayo Ajarkan Anak Tanggung Jawab Finansial, PT. Alex Media Komputindo, Kelompok Gramedia Jakarta.

Vol. 1 No. 2 Oktober 2018

AL - MUDARRIS homepage: http://e-journal.staima-alhikam.ac.id/index.php/almudarris/index 
Beritahukan pada siswa bahwa dengan menabung di bank, mereka akan bisa mendapatkan keuntungan lebih dari sekedar menabung di rumah dengan celengan. Apalagi, jika jenis tabungan yang dipilih khusus untuk anak-anak, yang pastinya memberikan banyak hadiah atau tawaran menarik lainnya. Biarkan antar siswa bersaing dalam hal ini dengan teman teman sekelasnya, sehingga mereka akan lebih termotivasi mencari cara untuk menambah penghasilannya untuk ditabung selain uang saku, misalnya membantu ibu atau ayah serta mencoba berjualan disekolah kepada temantemannya.

4. Pastikan siswa mengetahui hubungan antara bekerja dan gaji.

Biarkan siswa mengetahui berapa jam yang orangtua dan guru habiskan untuk bekerja untuk mendapatkan gaji. Jangan lupa, berikan pemahaman pada mereka bahwa negara berhak mengambil bagian dari gaji sebagai pajak untuk negara yang nantinya akan dikembalikan dalam pembangunan infrastruktur fasilitas umum.

5. Jangan pernah lelah mengajarkan siswa mengenai sistem kredit.

Berikan pemahaman pada anak mengenai kartu kredit dan bagaimana cara menggunakannya. Satu hal yang tidak diajarkan adalah pentingnya membayar tagihan setiap bulannya. Sebelum siswa memiliki kartu kredit, ajari dulu bagaimana pengaturan uangnya dengan menggunakan kartu debet yang dia miliki sekarang.

6. Jika usianya cukup, motivasi mereka untuk mendapatkan pengalaman bekerja.

Biarkan siswa merasakan rasanya bekerja part time, menerima gaji, dan mendapatkan potongan pajak sehingga mereka bisa menghargai uang.

7. Ajarkan anak mengenai investasi.

Dalam hal ini, pengalaman nyata adalah guru terbaik. Orangtua dan guru dapat menjadi contoh yang paling nyata bagi mereka. Dari pengalaman ini, anak bisa belajar mengenai proses, keuntungan, kerugian, faktor resiko, dan lain sebagainya.

Dari semua uraian di atas itu adalah membahas perihal kecerdasan finansial secara global, belum secara teknis dan detil. Hal yang pasti adalah bahwa kita tidak berhenti pada aspek mendapatkan uang semata, namun harus membekali anak didik kita dengan beberapa aspek yang lain. Kalau ada orang kaya ataupun keturunan orang kaya yang memiliki warisan, kemudian suatu hari ia jatuh miskin, maka tidak lain karena ia tidak memiliki bekal yang cukup tentang kecerdasan finansial.

Sebaliknya semakin tinggi pemahaman seseorang mengenai perencanaan keuangan, ia pun semakin ketagihan untuk menemukan dan membeli produk keuangan yang bisa memproteksi dirinya dan juga untuk berinvestasi atau untuk mengembangkan sayap bisnisnya.

Bagi Anda yang sudah mempunyai keahlian dan pengalaman tentang program pendidikan keuangan, tentu ini merupakan peluang usaha untuk membangun lembaga pendidikan keuangan tingkat anak sekolahan yang berumur sekitar $15-18$ tahun. Dengan adanya beberapa kriteria diatas, seharusnya kita tidak ada kesulitan untuk memulainya.

\section{DAFTAR PUSTAKA}

Abyz Wigati, 2017, Menumbuhkan Kecerdasan Finansial Pada Anak, mayamyworld.wordpress.com

Andri Priyatna, 2012, Ayo Ajarkan Anak Tanggung Jawab Finansial, PT. Alex Media Komputindo, Kelompok Gramedia Jakarta.

Daniel Goleman, 2006, Emotional Intelligence Why it Can Matter More Than IQ, Bantam Books, New York.

Vol. 1 No. 2 Oktober 2018

AL - MUDARRIS homepage: http://e-journal.staima-alhikam.ac.id/index.php/almudarris/index 
Darmawan Aji, 2015, 5 Kecerdasan Tentang Uang yang Wajib Anda Kuasai. https://www.darmawanaji.com/5-kecerdasan-tentang-uang-yang-wajib-andakuasai/

Elvyn G Masassya, 2012, 4 Langkah Mencapai Kecerdasan Finansial, https://lifestyle.kompas.com/read/2012/10/29/10040396/4.langkah.mencapai.kec erdasan.finansial/

Institut Ibu Profesional, 2017, Mendidik Anak Cerdas Finansial Sejak Dini, https://ummuchelia.wordpress.com

Jawa Post, 2018, Mengembangkan Kecerdasan Finansial Siswa, https://www.pressreader.com/indonesia/jawa-pos/20180327/282651803033679

Muslima, 2015, Pola Asuh Orang Tua Terhadap Kecerdasan Finansial Anak, Gender Equality Journal ISSN-P 2461-1468, E-ISSN-E 2548-1959 Vol 1 No 1 (2015) hal 85

Robert T. Kiyosaki, 2000, Rich Dad, Poor Dad, Gramedia Pustaka Utama.

Thomas A. Lucey, 2018, Financial Literacy for Children and Youth, Second Edition, Peter Lang AG International Academic Publishers

William Tanuwidjaja, 2009, 8 Intisari Kecerdasan Finansial, MedPress, hal 23

Yohanes Enggar Harisusilo, 2018, Kecerdasan Finansial Anak Usia Dini, https://edukasi.kompas.com. 